\title{
Empirical Research on Rate of Return, Interest Rate and Mudharabah Deposit
}

\author{
Inten Meutia Relasari ${ }^{1, *}$, and Achmad Soediro ${ }^{1}$ \\ ${ }^{1}$ Accounting Department Faculty Economic University Sriwijaya
}

\begin{abstract}
The objective of this study is to analyze the effects of interest rate and the rate of return on mudharabah deposits in Islamic banks. Using data covering the period from January 2012 to September 2015, the study applies the regression analysis to analyze the effect between variable and independence t- test to analyze the mean difference between rate of return and rate of interest. Regression analysis show that rate of return has negative influence significantly on mudharabah deposits, while interest rate has negative influence but not significant. The result of independent t-test shows that the interest rate is not different from the rate of return in Islamic Bank.
\end{abstract}

\section{Introduction}

Islamic banking is an activity based on Islamic Syariah principles, which does not allow the paying and receiving of interest and promotes profit sharing in the conduct of banking. The most important difference between Islamic and conventional banking is the prohibition of interest in Islamic banking [1]. Islamic financing works on the concept of buying and selling where the financial institution purchases the property and subsequently sells it to customers above the purchase price rate [2].

In the dual banking system where Islamic banking system operates in conjunction with the conventional banking system, such as in Indonesia, there will be a substantial relationship between the two systems. Changes in interest rates can have a pressure on the rate of return or profit-sharing in Islamic banking. [3] stated that when the interest rate in the conventional system increases, the Islamic banks need to increase their rate of return. The failure to respond this change can have an effect on the liquidity of the bank.

Therefore, the purpose of this paper is to investigate the influence of the rate of return and the interest rate on total time deposits mudharabah in the Islamic bank in Indonesia. In addition, this paper investigates whether the interest rate in conventional banks and the rate of return in Islamic banks in Indonesia are different significantly.

\section{Literature Review}

\subsection{Islamic Bank}

The primary and most vital feature of Islamic banks is that the prohibition of interest (riba), no matter its form or source. The prohibition of riba in Islamic social science has received a lot of attention. Several western studies have urged that the prohibition of interest is associated with degreeti-capitalist and an obstacle to the correct functioning of a contemporary economy and a prejudicious issue to economic development and growth [4]. [5] pointed out that for the conventional financial institution, the bottom lending charge (BLR) and prices of return on deposits would adjust according to alterations inside the industry fascination level. A rise on the market curiosity fee would cause the rate of return on deposits to increase. For the reason that Islamic bank is featuring lower deposit rates, it is unable to compete with the conventional bank in attracting new deposits. Consequently, the speed of progress of new deposits will have a tendency to decline. Simultaneously, depositors who would like to get benefit from the higher interest rates will transfer their deposits from the Islamic bank to the conventional financial institution. Customers may want to help keep their deposits for shorter length. Generally, the volume of Islamic deposits could be negatively influenced. The above rationalization theoretically exhibits that any change in the market interest rates would produce a shifting effect from Islamic bank to the conventional financial institution and vice versa.

\footnotetext{
* Corresponding author: relasari_mk@yahoo.co.iz
} 


\subsection{Interest Rate}

Rate of interest has always been featured as one of the important considerations in explaining the saving behavior of individual. The higher the rate of interest, the more money will be saved, since at higher interest rates people will be more willing to forgo present consumption. Interest rate risk is a major issue that needs serious attention from the bank. [7] illustrated that changes in interest rates may affect the bank both in terms of income and economic value. As in [3] stated that the constant increase in the interest rate will cause some problems, such as; the rising cost of funds of banks, because the banks have to pay more to attract new customers and retain existing customers. [8] stated that the risk rate of return is the most important risk faced by Islamic banking compared to other risks such as operational risk and liquidity risk.

Islamic banks obtain funding from two sources, namely 1) the public funds in bank deposits and 2) the public funds in non bank deposits. The former is comprised of wadiah demand deposit, Mudharabah saving deposits and Mudharabah time deposit. In the latter, there are received financing, securities issued by banks, interbank liabilities, liabilities to Bank Central and other payables [9].

In relation to the mudharabah time deposits, Islamic banks provide a rate of return to customers. The rate of return varies between banks because it depends on the bank's profit and the profit sharing ratio that determined at the beginning [10]. In theory, the rate of return on deposits is based on the profit sharing ratio agreed between the bank and the customer.

\subsection{Profit and Loss Sharing (Rate of Return)}

Profit- and loss-sharing (PLS) is a contractual agreement between two or more transacting parties that permit them to pool their resources to invest inside a project to share in financial profit and loss.

Profit sharing is a system for the distribution of net income between the owners (the first party) and fund managers (second party). Both sides agreed that the working capital provided from the first party to the second party will be managed professionally and responsibly [11].

\subsection{Mudharabah Deposit}

According to [12] mudharabah contract are the cornerstone of Islamic banking. Mudharabah is a profit sharing and loss bearing contract; and it may be used on both sides of the balance sheet assets and liabilities. It is a contract between the capital provider as rab al mal, whereby the capital provider would contribute capital to an enterprise or activity that is to be managed by the entrepreneur as mudarib.

In the case of time deposit, bank act as the mudharib. In fact usually, as a mudharib bank will set proportion for the result based on equivalent rate. So, the rab al mal will get the profit based on equivalent rate promised at the beginning contract. If the rate of return higher then there is a probability that total time deposit will be increased.

In the countries that have dual banking system like in Indonesia, capital provider also has access about interest rate in conventional bank. A rational depositor will take into account the amount of results that will be obtained by comparing the level of interest in conventional banks and the level of return of sharing in Islamic bank.

\subsection{Previous Research}

The relationship between total Islamic deposits and the conventional rate of return on deposits has been proved by [13]. A negative relationship between the interest rates on fixed deposits of conventional banks and the volume of interest- free investment deposits of Islamic banks was found.

A survey by [14] analysed that the relation between changes in the rate of interest of conventional bank deposits as well as the rate of return on Islamic bank deposits since 1984 to 2003. [15] found that Islamic banks in Malaysia commonly seen in conventional bank interest rate before adjusting the rate of return or profit. Research conducted by [16] also tried to analyse the effect of changes in interest rates on the level of profit-sharing in Islamic banks and the effect of changes in interest rates on savings deposits in conventional banks and Islamic banking.

Another study by [17] found that the interest rate in conventional banking is one of the main factors that determine the savings in Islamic banking in Indonesia. The same thing is expressed by [18] that the Islamic investment rate is closely linked to the interest rate in conventional banking.

[19] found a strong negative relationship between the interest rate and total deposits in Islamic banks. In another study [13] and [17] showed a negative relationship between the interest rate and total deposits in Islamic banks. In addition, [15] and [3] found a significant relationship between the rate of return of Islamic banks and interest rate of conventional bank and proved that changes in interest rates will cause a change in the level of profit- sharing in Islamic banking. Research conducted by [16] found that the total deposits in Islamic banks is significantly influenced by the rate of return.

Another study conducted by [20] also mentions that the Third-Party Funds (TPF) in Islamic banking is influenced by a conventional deposit rates. [9] states that there is an indication the rate of return on deposits mudharabah tend to mimic the interest rate by adjusting the level of financing and deposits. As in [18] find that in Malaysia only a small 
portion of Islamic bank financing is based on profit-loss sharing and that Islamic deposits are not interest-free, but closely pegged to conventional deposits, a finding confirmed by [21] for a sample of large Islamic banks across several countries.

The proposed hypothesis are as follows;

H1: Rate of return has influence on mudharabah deposit

H2: Interest rate has influence on mudharabah deposit

H3: There is no mean difference between rate of return and interest rate

\section{Methodology}

\subsection{Empirical Framework}

This study describes the relationship among a set of variables using regression analysis. In order to analyse the effect of Islamic banks' rate of return and conventional banks' interest rate to Islamic banks' total deposit in Indonesia, a regression model is utilized.

TOTDEP $=a+\beta 1$ IRCB $+\beta 2$ RRIB $+\varepsilon$ TOTDEP $=$ Total Mudharabah Deposit IRCB $=$ Interest Rate Conventional Bank RRIB $=$ Rate of Return Islamic Bank

$\mathrm{a}=$ intercept

$\beta 1$ and $\beta 2=$ coefficient

$\varepsilon=$ term of error

Next, this study conducts independent t-test to ascertain if there is a difference in mean between the rate of interest and rate of return.

\subsection{Data and analysis}

This study uses monthly data covering the period from January 2012 to September 2015. The reason for using 1 month deposit data because this deposit is more responsive with the change of interest rate or rate of return because the depositor can swift their fund quickly. Additionally, 1 month deposits is the largest source of deposits for Islamic banks and conventional deposits compared with 3,6 , or 12 months.

\section{Data and Empirical Result}

The descriptive statistics of variables are presented in Table 1 showing the mean, minimum and maximum for variables rate of return, interest rate, and total mudharabah deposit.

Table 1. Descriptive Statistic

\begin{tabular}{|l|c|c|c|c|}
\hline & N & Minimum & Maximum & Mean \\
\hline Rate of return & 45 & 3,34 & 7,74 & 6,2082 \\
\hline Interest rate & 45 & 5,43 & 6,84 & 6,1011 \\
\hline Mudharabah deposit & 45 & 19,597 & 69,106 & 42,3933 \\
\hline Valid N (listwise) & 45 & & & \\
\hline
\end{tabular}

The average rate of return stands at 6,2082 versus 6,1011 for interest rate. Table 1 indicates that minimum rate of return is lower than interest rate. The average Mudharabah deposit is 42,3933 with minimum 19,597 and maximum deposit 69,106 . Using regression analysis, the result shows that simultaneously there is a significant influence in rate of return and rate of interest on mudharabah deposit.

Table 2. Anova

\begin{tabular}{|c|c|c|c|c|c|}
\hline Model & $\begin{array}{l}\text { Sum of } \\
\text { Squares }\end{array}$ & $\mathrm{df}$ & $\begin{array}{l}\text { Mean } \\
\text { Square }\end{array}$ & F & Sig. \\
\hline Regression & 3167,939 & 2 & 1583,969 & 10,452 &, $000^{b}$ \\
\hline Residual & 6365,202 & 42 & 151,552 & & \\
\hline Total & 9533,140 & 44 & & & \\
\hline \multicolumn{6}{|c|}{ a. Dependent Variable: DPK } \\
\hline
\end{tabular}

Table 3 shows that there is significantly influence for rate of return to Mudharabah Deposit $(\mathrm{p}=0,002)$. While for rate of interest there is no significant influence $(\mathrm{p}=0,185)$ to Mudharabah Deposit. It means that $\mathrm{H} 1$ is accepted while $\mathrm{H} 2$ is rejected. 
Table 3. Regression Analysis

\begin{tabular}{|c|c|c|c|c|c|}
\hline \multirow[t]{2}{*}{ Model } & \multicolumn{2}{|c|}{$\begin{array}{l}\text { Unstandardized } \\
\text { Coefficients }\end{array}$} & $\begin{array}{l}\text { Standardized } \\
\text { Coefficients }\end{array}$ & \multirow[t]{2}{*}{$\mathrm{t}$} & \multirow[t]{2}{*}{ Sig. } \\
\hline & $\mathrm{B}$ & $\begin{array}{l}\text { Std. } \\
\text { Error } \\
\end{array}$ & Beta & & \\
\hline (Constant) & 122,807 & 21,245 & & 5,780 &, 000 \\
\hline RRIB & $-7,928$ & 2,404 &,- 465 & $-3,297$ & ,002 \\
\hline IRCB & $-5,113$ & 3,793 &,- 190 & $-1,348$ &, 185 \\
\hline
\end{tabular}

a. Dependent Variable: DPK

The significant negative influence between rate of return and total mudharabah deposit is consistent with [16] which found that rate of return influence mudharabah deposit in general. This indicates that the increase in rate of return will be impacted negatively to deposit in Islamic Bank.

The result also shows that there is a negative influence interest rate to mudharabah deposit but it is not significant. Although the finding is not significant but it is consistent with result from [13] and [17] that found a negative relationship between the interest rate and total deposits in Islamic banks. [22] in his research also found same conclusion. Furthermore to determine whether the rate of return and the interest rate are significantly different, we conduct tests of differences and report the results in Table 4 and table 5.

Table 4. Independent t test

\begin{tabular}{|l|l|l|l|l|}
\hline BANK & N & Mean & $\begin{array}{l}\text { Std. } \\
\text { Deviation }\end{array}$ & $\begin{array}{l}\text { Std. Error } \\
\text { Mean }\end{array}$ \\
\hline ISLAMIC BANK & 45 & 6,2082 &, 86406 &, 12881 \\
\hline $\begin{array}{l}\text { CONVENTIONAL } \\
\text { BANK }\end{array}$ & 45 & 6,1011 &, 54764 &, 08164 \\
\hline
\end{tabular}

Table 4 presents the average rate of return in Islamic Bank and interest rate in conventional bank. It seems that rate of return in Islamic Bank is higher than interest rate in Conventional Bank.

Table 5. Independent Samples Test

\begin{tabular}{|c|l|l|l|l|l|l|l|l|l|}
\hline \multicolumn{2}{|c|}{} & \multicolumn{2}{|l|}{$\begin{array}{l}\text { Levene's Test for } \\
\text { Equality of Variances }\end{array}$} & \multicolumn{2}{|l|}{ t-test for Equality of Means } \\
\cline { 2 - 9 } & F & SSig. & t & df & $\begin{array}{l}\text { Sig. (2- } \\
\text { tailed) }\end{array}$ & $\begin{array}{l}\text { Mean } \\
\text { Difference }\end{array}$ & $\begin{array}{l}\text { Std. Error } \\
\text { Difference }\end{array}$ \\
\hline \multirow{2}{*}{ PROCENTAGE } & $\begin{array}{l}\text { Equal variances } \\
\text { assumed }\end{array}$ & 2,950 &, 089 &, 702 & 88 &, 484 &, 10711 &, 15250 \\
\cline { 2 - 10 } & $\begin{array}{l}\text { Equal variances } \\
\text { not assumed }\end{array}$ & & &, 702 & 74,438 &, 485 &, 10711 &, 15250 \\
\hline
\end{tabular}

The value on Levene's Test shows significant at 0,089 higher than 0,05. It's means that both group (Islamic bank and conventional bank) have same variances, which is requirement for mean differences test. In Table 5 , significant value is 0,485 more than 0,05 .

It means that there is no mean difference between rate of return in Islamic Bank and interest rate in conventional bank. This is indicate that $\mathrm{H} 3$ is accepted. This finding shows that there is no difference between rate of return and interest rate. The result is in accordance with [9] that stated there is an indication the rate of return on deposits mudharabah tend to mimic the interest rate. Our finding also consistent with [15] who found that Islamic banks in Malaysia commonly seen in conventional bank interest rate before adjusting the rate of return or profit. This result emphasized by [16] that found the relationship between Islamic banks' rate of return and conventional banks' interest rate is shown to be very strong and positive.

\section{Conclusion}

Using regression analysis, the result found that the rate of return in Islamic bank influence mudharabah deposit negative significantly. This study also found that there is negative influence interest rate on Mudharabah Deposit, but it is not significant. This finding indicates profit motive among the Islamic bank depositors as reflected by the significant impact of the rate of return on total mudharabah deposits. 
Using independent t-test, the findings conclude that there is no difference in means of returns between Conventional and Islamic banks. This study however, has its own limitation whereby it is conducted within a limited time period and variables. Further extension of this research should consider a wider scope of deposits by conducting the same approach on different type of deposits available in Islamic banks and specific financial institutions categorized under Islamic financial institutions. Further extension of the study could consider the determinants of rate of return of the Islamic banks.

\section{References}

1. A. Andriyanti, and Wasilah, "Factors influences Third Party Funds in Muamalat Bank Indonesia (BMI)",SimposiumNasionalAkuntansi XIII Purwokerto. (2009),

2. M.Y. Nasir, and Hafiz, M.N. "Islamic Banking and Finance", 1st Edition. Kuala Lumpur, Malaysia. McGrawHill. (2006),

3. I. Bacha, "Dual banking systems and interest rate risk for Islamic banks", Available at www.fivepillarsassc.com/documentation/Dual-Banking-Systems.pdf, 2004).

4. R.N. Kayed, "The entrepreneurial role of profit-and-loss sharing modes of finance: theory and practice", International Journal of Islamic and Middle Eastern Finance and Management Vol. 5 no. 3, pp. 203-228. (2012).

5. S.A Rosly, Al-Bay' Bithamin Ajil financing: Impacts On Islamic Banking Performance, Thunderbird International Business Review, Vol. 41 no.4, pp 461-481. (1999)

6. M. Hanif, Differences and Similarities in Islamic and Conventional Banking, International Journal of Business and Social Science, Vol 2 No. 2, pp 166-175. (2011).

7. Basel Committee on Banking Supervision. "Principles for the Management and Supervision of Interest Rate Risk", Available at www.bis.org/publ/bcbs102. (2004).

8. Khan, T. and Ahmed. H. "Risk Management: An Analysis of Issues in Islamic Financial Industry", IRTI/IDB Occasional Paper, No. 5. (2001).

9. R. Ismal, "Islamic Banking in Indonesia. New Perspective on Monetary and Financial Issues", John Willey \& Son. Singapore Ltd. (2013).

10. D. Olson, and Zoubi, T. "Using Accounting Ratios to distinguish between Islamic and Conventional Banks in the GCC Region”, The International Journal of Accounting, Vol. 43, pp. 45-65. (2008).

11. M.R.N Akhtar,."Musharakah financing for small enterprise in Pakistan", in Harper, M. (Ed.), Partnership Financial for Small Enterprise: Some lessons from Islamic Credit Systems, ITDG Publications, Rugby, pp. 35-41. (1997).

12. A.M El Thiby ,"Islamic Banking. How to Manage Risk and Improve Profitability", John Willey \& Son.Inc. New Jersey. (2011).

13. S. Haron, and Ahmad, N. "The effects of conventional interest rates and rate of profits on funds deposited with Islamic banking system in Malaysia”, International Journal of Islamic Financial Services, Vol. 1 No. 4, pp. 17.(2000).

14. I.B. Obiyathulla, "The Islamic interbank money market: an analysis of risks", Asian Islamic Banking SummitWorkshop II - Implementing Islamic Money Market: Issues and Challenges, 23 September 2004. Kuala Lumpur. (2004).

15. A. Kaleem , and M. Md Isa."Causal relationship between Islamic and conventional banking instruments ", International Journal Of Islamic Financial Services, Vol.4 No. 4, pp. 1-8.(2003).

16. Z. Zainol, and Kassim, S.H. "An Analysis of Islamic Banks' Exposure to Rate of Return Risk", Journal of Economic Cooperation and Development, Vol. 31 No.1, pp. 59-84. (2010).

17. R.A Kasri, and Kassim, S.H. "Empirical determinants of saving of the Islamic banks in Indonesia", Journal of King Abdul Aziz University: Islamic Economics, Vol. 22 No. 2, pp.3-23.(2009).

18. B.S. Chong, and Liu, M.-H. "Islamic banking: Interest-free or interest-based? “,Pacific-Basin Finance Journal, Vol.17 No.1, pp.125-144.(2008).

19. S. Haron, and Shanmugam, B. The Effect of rates of profit on Islamic bank's deposit: a note, Journal of Islamic Banking and Finance, Vol.12 No. 2, pp.18-28.(1995).

20. Farikh, Nurdian, "Analysis factors influences Third Party Fund in Islamic Bank and Conventional Bank in Indonesia”, Unpublished Thesis PSKTTI.UI. (2007).

21. O. Khan, "An Examination of the Underlying Rationale of the Profit and Loss Sharing System, With Special Emphasis on the Mudharabah and Musharakah Within the Context of Islamic Law and Banking", Journal of Finance, Accounting \& Management, Vol. 3 No.1, pp. 23-31. (2012).

22. I.J. Mangkuto, "The Influence Rate of Return Conventional Deposit and Rate of Return Mudharabah Deposit to Deposit Growth in Muamalat Bank Indonesia", Unpublished Thesis. PSKTTI UI. (2004). 